\title{
Kistik Ekinokokkozis Ön Tanılı Hastalarda Anti-Echinococcus granulosus Antikorlarının Araştırılması
}

Investigation of Anti-Echinococcus granulosus Antibodies in Patients with Suspected Cystic Echinococcosis

\author{
Ülfet Çetinkaya, Berna Hamamcı, Muhittin Kaya, Süheyla Gücüyetmez, Salih Kuk, \\ Süleyman Yazar, İzzet Şahin
}

Erciyes Üniversitesi Tıp Fakültesi, Parazitoloji Anabilim Dalı, Kayseri, Türkiye

\section{ÖZET}

Amaç: Bir helminto-zoonoz olan kistik ekinokokkozis (KE), gelişmekte olan ülkelerde hem sağlığı tehdit eden hem de ekonomik kayıplara sebep olan önemli bir hastalıktır. Bu çalışmada, Erciyes Üniversitesi Tıp Fakültesi Parazitoloji Anabilim Dalı'na Haziran 1999-Temmuz 2010 tarihleri arasında KE ön tanısı ile başvuran 701'i (\%45.1) erkek, 855'i (\%54.9) kadın olmak üzere toplam 1556 hastanın anti-Echinococcus granulosus antikorları değerlendirilmiştir.

Yöntemler: Hastaların 56'sında (\%3.6) Indirekt Hemaglütinasyon (IHA), İndirekt Fluoresans Antikor Tekniği (IFAT) ve Western blot (WB); 378'inde (\%24.3) IHA ve IFAT; 123'ünde (\%7.9) IHA ve WB; 999'unda (\%64.2) ise bu üç yöntemden herhangi biri kullanılmıştır.

Bulgular: Söz konusu üç yöntemden en az biri ile anti-E. granulosus antikorları saptanan 353 (\%22.7) hasta pozitif olarak değerlendirilmiştir. Sonuç: Bazı hastaların bir testle pozitif diğer bir testle negatif bulunmasından dolayı KE'nin serolojik tanısında en az iki testin birlikte kullanıımasının daha güvenilir olacağı kanısına varıımıştır. (Turkiye Parazitol Derg 2012; 36: 57-60)

Anahtar Sözcükler: Echinococcus granulosus, IHA, IFAT, WB

Geliş Tarihi: 05.10.2010

Kabul Tarihi: 17.02.2012

\section{ABSTRACT}

Objective: Cystic echninococcosis (CE) is an important helmintho-zoonotic disease causing health-threatening and economic losses for developing countries. In this study, anti-Echinococcus granulosus antibodies were evaluated in 1556 CE suspected patients (701 males, 855 females) who applied to the serology laboratory of the Parasitology Department of Erciyes University between June 1999 and July 2010.

Methods: Fifty-six (3.6\%) patients were evaluated with the three different methods of Indirect Hemagglutination Test (IHA), Indirect Fluorescent Antibody Test (IFAT) and Western blot (WB). 378 (24.3\%) were tested with both IHA and IFAT, 123 (7.9\%) with both IHA and WB, and 999 (64.2\%) were evaluated with one of these three methods.

Results: In 353 (22.7\%) patients, anti-E. granulosus antibodies detected by one of above three methods were considered as positive.

Conclusion: Since some patients were assessed either as negative or positive with one of above test, we believe that it should be safer to use at least two tests together for diagnosis of CE. (Turkiye Parazitol Derg 2012; 36: 57-60)

Key Words: Echinococcus granulosus, IHA, IFAT, WB

Received: 05.10.2010

Accepted: 17.02.2012

\section{Bu çalışma 5. Ulusal Hidatidoloji Kongresi'nde (22-25 Eylül 2010, Antakya) sunulmuştur.}

Yazışma Adresi / Address for Correspondence: Dr. Ülfet Çetinkaya, Erciyes Üniversitesi Tıp Fakültesi, Parazitoloji Anabilim Dalı, Kayseri, Türkiye Tel: +90 5334213393 E-posta: ucetinkaya@erciyes.edu.tr 


\section{GiRiş}

Echinococcus granulosus (E. granulosus)'un larva şeklinin insanlarda ve koyun, sığır gibi otçul hayvanların çeşitli organlarında yerleşmesiyle meydana gelen kistik ekinokokkozis (KE), hem hayvanlarda hem de insanlarda sağlığı tehdit eden ve önemli ekonomik kayıplara sebep olan bir hastalıktır (1-3). Erişkin paraziti bağırsaklarında barındıran karnivor konakların dışkılarıyla atılan E. granulosus yumurtaları insan ve doğal ara konak olan koyun, keçi, sığır gibi değişik türden hayvanlarda enfeksiyona sebep olmaktadır. Parazitin başta karaciğer olmak üzere; akciğer, böbrek, dalak, beyin, kemik, kalp gibi hemen her organa yerleştiği bilinmektedir (4).

Hastalığın tanısında her ne kadar görüntüleme yöntemleri ön planda tutulsa da komplike vakaların ve operasyon sonrası nükslerin daha sağlıklı bir şekilde değerlendirilebilmesi için ön tanının serolojik tanı yöntemleriyle desteklenmesi gerekmektedir. Diğer taraftan, bazı kişilerde kistin büyüklüğüne, lokalizasyonuna, yapısına, canlıı̆̆ına ve kişinin immün aktivitesine bağlı olarak antikor oluşmadığı, bu nedenle negatif serolojik test sonuçlarının KE tanısından uzaklaştırmaması gerektiği de bir gerçektir $(4,5)$.

Bu çalışmada, Haziran 1999-Temmuz 2010 tarihleri arasında Erciyes Üniversitesi Tıp Fakültesi Parazitoloji Anabilim Dalı'na KE ön tanısı ile başvuran 1556 hastada elde edilen anti-E. granulosus antikorları değerlendirilmiştir.

\section{YÖNTEMLER}

Çalışmamızda, farklı kliniklerden KE ön tanısı ile başvuran 1556 hastanın serum örneklerinde anti-E. granulosus antikorları araştırılmışıtır. Hastaların 56'sında (\%3.6) IHA, IFAT ve WB; 378'inde (\%24.3) IHA ve IFAT; 123'ünde (\%7.9) IHA ve WB; 999'unda (\%64.2) ise bu üç yöntemden herhangi biri kullanılımışır. Çalışmada kullanılan ticari kitler (IHA: Hydatidose, Fumouze Laboratoires, France; IFAT: Euroimmun GmbH, Germany; WB: Euroimmun $\mathrm{GmbH}$, Germany) test prosedürlerine uygun olarak çalışılmıştır. IFAT ile çalışılan örnekler fluoresan mikroskobunda 450-490 nm dalga boylu filtrede $\times 400$ büyütmede değerlendirilmiş olup fluoresan verenler; IHA testi ile çalışıan örnekler makroskobik olarak değerlendirilmiş olup kenarları tırtıklı bir halka veya homojen bir şekilde bulanıklık verenler; WB ile çalısılan örneklerde ise p7 bandı (Şekil 1) oluşanlar pozitif olarak kabul edilmiştir.

İstatistiksel değerlendirmeler için SPSS for Windows V.15.0 paket programı kullanılarak Ki-kare testi yapılmış, $\mathrm{p}<0.05$ anlamlı olarak kabul edilmiştir.

\section{BULGULAR}

Çalışmada; Haziran 1999-Temmuz 2010 tarihleri arasında Erciyes Üniversitesi Tıp Fakültesi Parazitoloji Anabilim Dalı laboratuvarına KE şüphesi ile farkı kliniklerden gönderilen 701'i (\%45.1) erkek, 855'i (\%54.9) kadın toplam 1556 hasta serumunda antiE. granulosus IgG antikorları araştııılmıştır. Serumların 353'ünde (\%22.7) söz konusu üç yöntemden en az biri ile anti-E. granulosus antikorları tespit edilmiş ve pozitif olarak değerlendirilmiştir. Hastaların yıllara göre seropozitiflik değerleri Tablo 1'de sunulmuştur.

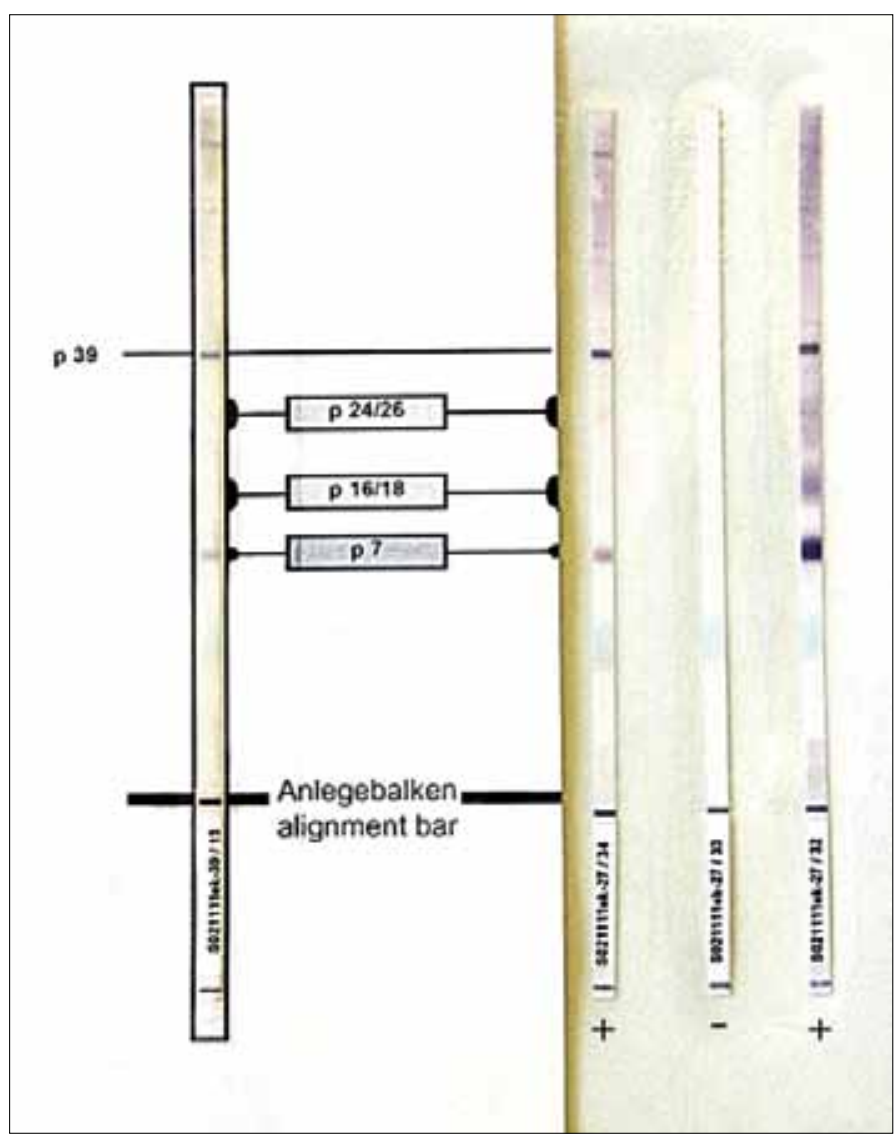

Şekil 1. Western blot ile alınan sonuçlar

Tablo 1. Yıllara göre E. granulosus seropozitifliği

\begin{tabular}{|l|c|c|c|c|}
\hline \multirow{2}{*}{ Yillar } & \multicolumn{2}{|c|}{ Pozitif } & \multicolumn{2}{c|}{ Negatif } \\
\cline { 2 - 5 } & $\mathbf{n}$ & $\%$ & $\mathbf{n}$ & $\%$ \\
\hline $1999 *(n=67)$ & 21 & 31.3 & 46 & 68.7 \\
\hline $2000(n=100)$ & 30 & 30 & 70 & 70 \\
\hline $2001(n=89)$ & 33 & 37.1 & 56 & 62.9 \\
\hline $2002(n=109)$ & 13 & 11.9 & 96 & 88.1 \\
\hline $2003(n=114)$ & 34 & 29.8 & 80 & 70.2 \\
\hline $2004(n=134)$ & 33 & 24.6 & 101 & 75.4 \\
\hline $2005(n=115)$ & 27 & 23.5 & 88 & 76.5 \\
\hline $2006(n=136)$ & 38 & 27.9 & 98 & 72.1 \\
\hline $2007(n=164)$ & 36 & 22 & 128 & 78 \\
\hline $2008(n=228)$ & 36 & 15.8 & 192 & 84.2 \\
\hline $2009(n=188)$ & 37 & 19.7 & 151 & 80.3 \\
\hline 2010 ** (n=112) & 15 & 13.4 & 97 & 86.6 \\
\hline Toplam (n=1556) & 353 & 22.7 & 1203 & 77.3 \\
\hline *1999 yilnnin son altı ayı, *2010 yilınin ilk altı ayı \\
\hline
\end{tabular}

Anti-E. granulosus antikorları saptanmış olan hastaların \%38.5'ini erkeklerin, \%61.5'ini ise kadınların oluşturduğu saptanmıştır (Tablo 2). Yapılan istatistiksel analizde; antikor pozitifliği açısından kadın ve erkekler arasındaki farkın anlamlı olduğu belirlenmiştir ( $\left.X^{2}: 7.851, p=0.003\right)$. 
Tablo 2. Cinsiyete göre E. granulosus seropozitifliği

\begin{tabular}{|l|c|c|c|c|}
\hline \multirow{2}{*}{ Cinsiyet } & \multicolumn{2}{|c|}{ Pozitif } & \multicolumn{2}{c|}{ Negatif } \\
\cline { 2 - 5 } & $\mathbf{n}$ & $\%$ & $\mathbf{n}$ & $\%$ \\
\hline Erkek $(\mathrm{n}=701)$ & 136 & 38.5 & 565 & 47 \\
\hline Kadın $(\mathrm{n}=855)$ & 217 & 61.5 & 638 & 53 \\
\hline Toplam (n=1556) & 353 & 22.7 & 1203 & 77.3 \\
\hline
\end{tabular}

Üç yöntemle değerlendirilen 56 hastanın 36'sı (\%64.3) her üç yöntemle negatif, 11'i (\%19.6) pozitif, 2'si (\%3.6) IHA ile negatifken diğer iki yöntemle pozitif, 7'si (\%12.5) ise sadece WB ile pozitif bulunmuştur (Tablo 3).

Sadece IHA ve IFAT ile çalışılan 378 hastanın 325'i (\%86) her iki yöntemle negatif, 47'si (\%12.4) pozitif, 4'ü (\%1.1) IHA ile pozitifken IFAT ile negatif, 2'si (\%0.5) ise IFAT ile pozitifken IHA ile negatif bulunmuştur (Tablo 4).

Sadece IHA ve WB ile çalışılan 123 hastanın 87'si (\%70.7) her iki yöntemle negatif, 30'u (\%24.4) pozitif, 6'sı (\%4.9) ise WB ile pozitifken IHA ile negatif bulunmuştur. Western blot yöntemi ile negatif bulunan hastaların tamamı IHA ile de negatif bulunmuştur (Tablo 5).

Üç yöntemden sadece herhangi biri ile çalışılan 999 hastanın ise 244'ü (\%24.4) pozitif bulunmuştur.

\section{TARTIŞMA}

Kistik ekinokokkozis, günümüzde ciddi eradikasyon programlarının olmaması, başıboş köpek populasyonunun fazlalığı, kasaplık hayvan kesimlerinin tamamıla kontrol altına alınamamış olması, halkın hastalık konusunda yeterince bilinçlendirilememiş olması ve sayılabilecek daha birçok faktörlere bağlı olarak devam etmektedir (6).

Ülkemizde yapılan bazı çalışmalarda serolojik verilere göre KE olasılı̆̆ı; İzmir'de \%3.45 (1), Afyon'da \%14.6 (7), Manisa'da \%0.4 (8), Ankara'da \%54.1 (9) olarak bildirilmiştir. Yazar ve arkadaşlarının (10) ülke genelinde yapmış oldukları retrospektif bir çalışmada KE oranları; Marmara Bölgesi'nde \%13.13, Ege Bölgesi'nde \%16.94, Akdeniz Bölgesi'nde \%16.09, İç Anadolu Bölgesi'nde \%38.57, Karadeniz Bölgesi'nde \%5.70, Doğu Anadolu Bölgesi'nde \%6.80, Güneydoğu Anadolu Bölgesi'nde ise \%2.75 olarak bildirilmiştir.

Şehrimizde yapılan diğer çalışmalara bakıldığında; Yazar (6), 1994-1998 yıllarını kapsayan ve hastane kayıtlarını inceleyerek yapmış olduğu bir çalışmada; beş yıllık periyotta Kayseri'deki hastanelerden toplam 349 KE olgusunun saptandığını, ayrıca olgu sayısının nüfusa oranının 1/14.364 (§7/100.000) olduğunu bildirmiştir. Yazar'ın (11) 1999-2004 yıllarını kapsayan ve yine hastane kayıtlarını inceleyerek yapmış olduğu diğer bir çalışmada ise toplam $699 \mathrm{KE}$ olgusunun saptandığı, olgu sayısının nüfusa oranının 1/9.098 (@11/100.000) olduğu bildirilmiştir. Yazar ve ark. (12) Kayseri'de 2242 kişi üzerinde yapmış oldukları seroepidemiyolojik bir çalışmada ise; ELISA ve IFAT ile \%2.72, Western blot yöntemiyle \%0.94 seropozitiflik saptanmışıı. Çalışmamızda, 1556 hastanın 353'ünde (\%22.7) anti-E. granulosus antikorları saptanmıştır. Türkiye'de yapılan birçok çalışmada kadınlarda hastalığın daha fazla görüldüğü bildirilmiştir (11, 13-16). Bizim olgularımız-
Tablo 3. Her üç yöntemle değerlendirilen hastalarda E. granulosus seropozitifliği

\begin{tabular}{|l|c|c|c|c|}
\hline \multirow{2}{*}{ IHA } & \multirow{2}{*}{ IFAT } & \multicolumn{2}{|c|}{ WB } & \multirow{2}{*}{ Toplam } \\
\cline { 3 - 4 } & & Pozitif & Negatif & \\
\hline Pozitif & Pozitif & $11(\% 55)$ & $0(\% 0)$ & 11 \\
\hline & Negatif & $0(\% 0)$ & $0(\% 0)$ & 0 \\
\hline Negatif & Pozitif & $2(\% 10)$ & $0(\% 0)$ & 2 \\
\hline & Negatif & $7(\% 35)$ & $36(\% 100)$ & 43 \\
\hline Toplam & & 20 & 36 & 56 \\
\hline
\end{tabular}

Tablo 4. Sadece IHA ve IFAT ile değerlendirilen hastalarda E. granulosus seropozitifliği

\begin{tabular}{|l|c|c|c|}
\hline \multirow{2}{*}{ IHA } & \multicolumn{2}{|c|}{ IFAT } & \multirow{2}{*}{ Toplam } \\
\cline { 2 - 3 } & Pozitif & Negatif & \\
\hline Pozitif & $47(\% 95.9)$ & $4(\% 10.3)$ & 51 \\
\hline Negatif & $2(\% 4.1)$ & $325(\% 98.8)$ & 327 \\
\hline Toplam & 49 & 329 & 378 \\
\hline
\end{tabular}

Tablo 5. Sadece IHA ve WB ile değerlendirilen hastalarda E. granulosus seropozitifliği

\begin{tabular}{|l|c|c|c|}
\hline \multirow{2}{*}{ IHA } & \multicolumn{2}{|c|}{ WB } & \multirow{2}{*}{ Toplam } \\
\cline { 2 - 3 } & Pozitif & Negatif & \\
\hline Pozitif & $30(\% 83.3)$ & $0(\% 0)$ & 30 \\
\hline Negatif & $6(\% 16.7)$ & $87(\% 100)$ & 93 \\
\hline Toplam & 36 & 87 & 123 \\
\hline
\end{tabular}

da da benzer şekilde kadınlardaki oran yüksek bulunmuştur (\%61.5).

Karaman ve ark. (16) Kars'ta yaptıkları bir çalışmada hasta örneklerini manuel olarak hazırladıkları IHA ve ticari IFA testi kullanarak değerlendirmişler ve her iki yöntemle \%34.6 seropozitiflik belirlediklerini bildirmişlerdir. Delibaş ve ark. (17) İzmir'de yaptıkları bir çalışmada inceledikleri 465 hastanın \%17'sini ELISA ile \%14'ünü ise IHA ile pozitif bulduklarını, her iki test ile hastaların sadece \%12'sini pozitif bulduklarını bildirmişlerdir. Sarı ve ark. (18) ELISA, IFAT ve IHA yönteminin duyarlılık ve özgüllüklerini araştırdıkları bir çalışmada KE'li 40 olgunun $35^{\prime}$ inde (\%87.5) ELISA, 33 'ünde (\%82.5) IFAT ve 36'sında (\%90) IHA yöntemi ile metasestoda özgü antikor cevap saptadıklarını ve ELISA yönteminin duyarlılı̆ının \%87.5, özgüllüğü \%100, IHA yönteminin duyarlılı̆ının \%90, özgüllüğünün \%97.5 ve IFAT yönteminin duyarlılığının \%82.5, özgüllüğünün ise \%100 olarak belirlediklerini bildirmişlerdir. Ayrıca kontrol grubu olarak çalışma kapsamına aldıkları taeniasisli bir (\%2.5) olgunun IHA yöntemi ile 1/160 serum sulandırımında çapraz reaksiyon verdiğini tespit etmişlerdir. Bizim çalışmamızda da IHA ve IFAT sonuçları arasında azda olsa uyumsuzluklar bulunmaktadır. Buna ek olarak IHA yöntemi veya IFAT ile negatif olarak belirlediğimiz halde WB ile pozitif olarak değerlendirdiğimiz 15 (\%4.24) vaka da mevcuttur. Hastane kayıtlarına dayalı çalışmalar ile seroepidemiyolojik çalışmalar arasında öteden beri farklılıklar bulunmaktadır. Bu farklıık; parazitle karşılaşan, dolayısıyla seropozitif olan bazı kişilerde kliniğin gelişmeme- 
si ya da kistin hastada şikâyet oluşturacak büyüklüğe ulaşmaması gibi durumlarla izah edilse de, bu durumdan serolojik testlerde karşılaşılan başka parazitlerle olan çapraz reaksiyonların ve kullanılan testlerin sensitivite ve spesifite farklılıklarının da sorumlu olabileceği düşünülebilir. Çalışmada farklı kliniklerden gönderilen hastalar serolojik olarak değerlendirilmiş olup hastaların takipleri ilgili anabilim dalları tarafından yapıldığından söz konusu bilgilere ulaşılamamıştır ki, bu da çalışmanın bir kısıtılığı olarak belirlenmiştir.

Kistik ekinokokkozisin serolojik tanısında bilinen bütün yöntemler kullanılabilmektedir (19). Serolojik tanıda kullanılan testlerin duyarlılık ve özgüllüğünün kullanılan antijenin özelliklerine, antijenin elde edildiği konağa, hastanın antikor yanıtına, seçilen yönteme göre değiştiği bildirilmiştir (20). KE tanısında IHA yönteminin, kolay uygulanabilmesi, kısa süre içinde sonuç vermesi ve pahalı laboratuvar gereçleri gerektirmemesi nedenleri ile sıklıkla kullanıldığı bilinmektedir. Özellikle karaciğer yerleşimli KE olgularının tanısında kullanılan IFAT'ın duyarlılığının yüksek olduğu saptanmıştır. Ayrıca testin kolay uygulanır olması ve kısa sürede sonuç vermesinden dolayı tercih edilebileceği ifade edilmektedir (19).

\section{SONUÇ}

KE'nin serolojik tanısında tek bir testin kullanımı bazen yetersiz kalabilmektedir. Bu nedenle en az iki testin birlikte kullanılmasının daha güvenilir olacağı, ayrıca uygulanması nispeten zor olan WB yönteminin IFAT ve IHA yöntemleri ile kombinasyonunun duyarlılığı çok daha arttıracağı kanısına varılmıştır.

\section{Çıkar Çatışması}

Yazarlar herhangi bir çıkar çatışması bildirmemişlerdir.

\section{KAYNAKLAR}

1. Altıntaş N, Yazar S, Yolasığmaz A, Akısü Ç, Şakru N, Karacasu F, et al. A serum epidemiological study of cystic echinocococcosis in Izmir and its surrounding area. Turkey Helminthologia 1999; 36: 19-23.

2. Özbilgin A, Kilimcioğlu AA. Kistik Echinococcosis. Özcel MA, Özbel Y, Ak M, editors. Özcel'in Tıbbi Parazit Hastalıkları. İzmir: Meta basıms;2007.p. 541-66.

3. Yazar S, Altıntaş N. Serodiagnosis of cystic echinococcosis in Turkey. Helminthologia 2003; 40: 9-13.

4. Yazar S. Cystic Echinococcosis (CE)'in tanısında SDS-PAGE ve Western Blot yönteminin diğer serolojik tanı yöntemleri ile karşılaştırılması (Doktora tezi). İzmir: Ege Üniversitesi Tıp Fakültesi Parazitoloji Anabilim Dalı. 1998.
5. Delibaş SB, Ozkoç S, Sahin S, Aksoy U, Akisü C. Evaluation of patients presenting with a suspicion of cystic echinococcosis to the serology laboratory of the Parasitology Department of Dokuz Eylül University Medical Faculty. Türkiye Parazitol Derg 2006; 30: 279-81.

6. Yazar S. Kayseri'de Kistik Ekinokokkozis. Türkiye Parazitol Derg 2002; 26: 180-2.

7. Çetinkaya Z, Çiftçi IH, Demirel R, Altındiş M, Ayaz E. A sero-epidemiologic study on cystic echinococcosis in Midwestern region of Turkey. Saudi Med J 2005; 26: 350-1.

8. Kilimcioğlu AA, Ozkol M, Bayindir P, Girginkardeşler N, Ostan I, Ok UZ. The value of ultrasonography alone in screening surveys of cystic echinococcosis in children in Turkey. Parasitol Int 2006; 55: 273-5. [CrossRef]

9. Eşgin $M, A$ ktaş $M$, Coşkun Ş. The investigation of antibody presence in the sera of patients with a suspicion of cystic echinococcosis by using indirect hemaglutination test (IHA). Türkiye Parazitol Derg 2007; 31: 283-7.

10. Yazar S, Taylan Özkan A, Hökelek M, Polat E, Yılmaz H, Özbilge H, et al. Cystic echinococcosis in Turkey from 2001-2005. Türkiye Parazitol Derg 2008; 32: 208-20.

11. Yazar S. Cystic echinococcosis in Kayseri during the last six years. Türkiye Parazitol Derg 2005; 29: 241-3.

12. Yazar S, Yaman O, Çetinkaya F, Şahin i. Cystic echinococcosis in Central Anatolia, Turkey. Saudi Med J 2006; 27: 205-9.

13. Canda MŞ. Ekinokokkozis: 47 olgunun sunumu ve Türkiye'nin Ekinokokkozis sorunu. Türkiye Parazitol Derg 1995; 19: 64-82.

14. Gündoğdu C, Arslan R, Arslan MÖ, Gıcık Y. Evaluation of cystic and alveolar echinococcosis cases in people in Erzurum and surrounding cities. Türkiye Parazitol Derg 2005; 29: 163-6.

15. Hakverdi S, Sayar H, Yaldiz M, Erdoğan S, Akansu B, Canda MS. Unusual localization of echinococcosis in Cukurova (134 cases). Türkiye Parazitol Derg 2009; 33: 77-81.

16. Karaman Ü, Miman Ö, Kara M, Gıcık Y, Aycan MÖ, Atambay M. Hydatid cyst prevalence in the region of Kars. Türkiye Parazitol Derg 2005; 29: 238-40.

17. Delibaş SB, Ozkoç S, Sahin S, Aksoy U, Akisü C. Evaluation of patients presenting with a suspicion of cystic echinococcosis to the serology laboratory of the Parasitology Department of Dokuz Eylül University Medical Faculty. Türkiye Parazitol Derg 2006; 30: 279-81.

18. Sari C, Ertuğ S, Karadam SY, Ozgün H, Karaoğlu AO, Ertabaklar H. The comparative evaluation of Enzyme Linked Immunosorbent Assay (ELISA), Indirect Hemagglutination Test (IHA) and Indirect Fluorescent Antibody Test (IFAT) in the diagnosis of cystic echinococcosis. Türkiye Parazitol Derg 2009; 33: 73-6.

19. Biava MF, Dao A, Fortier B. Laboratory diagnosis of cystic hydatic disease. World J Surg 2001; 25: 10-4. [CrossRef]

20. Gottstein B. Molecular and immunological diagnosis of echinococcosis. Clin Microbiol Rev 1992; 7: 248-61. 